\title{
Phylogenetic analysis of viral haemorrhagic septicaemia virus (VHSV) isolates from France (1971-1999)
}

\author{
R. Thiéry ${ }^{1, *}$, C. de Boisséson ${ }^{2}$, J. Jeffroy ${ }^{1}$, J. Castric $^{1}{ }^{1}$ P. de Kinkelin ${ }^{3}$, \\ A. Benmansour ${ }^{3}$
}

\begin{abstract}
${ }^{1}$ Agence Française de Sécurité Sanitaire des Aliments, Site de Brest, Unité Pathologie Infectieuse et Parasitaire des Poissons BP 70, 29280 Plouzané, France

${ }^{2}$ Agence Française de Sécurité Sanitaire des Aliments, Site de Ploufragan, Unité Génétique Virale et Biosécurité, BP 53, 22440 Ploufragan, France

${ }^{3}$ Institut National de la Recherche Agronomique, Unité de Virologie et Immunologie Moléculaires, 78352 Jouy-en-Josas, Cédex, France
\end{abstract}

\begin{abstract}
The nucleotide sequences of a specific region of the glycoprotein gene were compared among 63 strains of viral haemorrhagic septicaemia virus (VHSV) isolated from fish in France between 1971 and 1999. The analysis was performed on a region corresponding to amino acids 238 to 331 of the glycoprotein gene, also designated the V2 region and previously shown to accumulate most of the mutations. The sequences of many VHSV isolates were found to be identical or very conserved. An isolate, designated L59X, obtained from elver in the Loire estuary, depicted a higher degree of divergence compared to the other French isolates. The deduced amino-acid sequences were analysed together with the results of neutralisation tests performed using monoclonal antibody $168 \mathrm{~m} 4$ specific to serotype 1. Non-neutralised VHSV strains had mutations in the region corresponding to the previously described $168 \mathrm{~m} 4$ epitope. Phylogenetic analysis showed that all the VHSV isolates studied, except L59X, belong to genotype I, previously described as containing VHSV strains isolated from continental Europe. Most of the VHSV isolates studied were found to be genetically related to one of the previously described VHSV strains representative of the major serotypes. Isolate L59X, which was the only French marine strain studied, was found to belong to genotype II, previously shown to encompass the VHSV strains isolated from the British Isles coastal waters. Overall there was a good correlation between the geographical origin of the studied isolates and their genetic characteristics.
\end{abstract}

KEY WORDS: Viral haemorragic septicaemia virus $\cdot$ Novirhabdoviruses $\cdot$ Phylogeny $\cdot$ Glycoprotein Resale or republication not permitted without written consent of the publisher

\section{INTRODUCTION}

Viral haemorrhagic septicaemia (VHS) is an infectious virosis of fish which mainly impacts on the rainbow trout Oncorhynchus mykiss (Walbaum) farming industry in continental Europe, but may represent an emerging risk for many other fish species.

The causative agent of VHS, viral haemorrhagic septicaemia virus (VHSV), belongs to the novirhabdovirus genus (van Regenmortel et al. 2000), together with

*E-mail: r.thiery@brest.afssa.fr other fish viruses, infectious hematopoietic necrosis virus (IHNV) and hirame rhabdovirus (HIRRV). The genome of VHSV is composed of a non-segmented single-stranded RNA molecule of 11158 nucleotides (nt) that has been fully sequenced (Schutze et al. 1999). It encodes 5 structural proteins: the nucleoprotein $\mathrm{N}$, the phosphoprotein $\mathrm{P}$, the matrix protein $\mathrm{M}$, the glycoprotein $\mathrm{G}$, the polymerase $\mathrm{L}$ and an additional nonvirion protein NV. Genes are arranged in the order 3'N-P-M-G-NV-L-5'.

Until 1987 VHS was considered to be a continental European fresh-water fish infection even though 2 
cases in sea water-reared rainbow trout had been reported (Castric \& de Kinkelin 1980, Horlyck et al. 1984). However, in both these outbreaks, infected fish originated from inland VHS-infected areas. Similarly, VHSV of freshwater origin (isolate 07-71) has also been experimentally demonstrated to infect 2 marine fish species, sea bass Dicentrarchus labrax and turbot Scophthalmus maximus, following water-borne infection (Castric \& de Kinkelin 1984).

The accepted epidemiology of VHS changed in 1987, after it was established (Jørgensen \& Olesen 1987) that a rhabdovirus isolated from cod Gadus morhua in the Baltic Sea, 8 yr before (Jensen et al. 1979), was indistinguishable from VHSV. Since then, VHSV has been recovered from several fish species caught in Pacific North Western coastal areas of the United States of America, and the North Atlantic and related sea areas (Castric et al. 1992, Ross et al. 1994, Meyers \& Winton 1995, Mortensen et al. 1999).

Studies of the sequence variations of the glycoprotein (G) gene of VHSV made it possible to delineate 3 different lineages designated genotypes I, II and III for continental European virus, turbot virus (North Atlantic) and Pacific virus respectively (Benmansour et al. 1997). Another study, completed independently from the previous one (Stone et al. 1997), also resulted in similar genetic grouping. The link of lineage and geographic origin of virus strains is thus clearly established through the 2 series of investigations. The virus lineage of VHSV isolates studied was independent of the fish-host species they were recovered from. More recently, novel genetic studies were conducted within genotype II (Snow et al. 1999). They were based upon the analysis of the nucleoprotein gene of 39 VHSV isolates from European marine origin belonging to genotype II and resulted in a sub-grouping of the virus strains according to their respective geographical area of origin.

The primary genetic grouping of VHSV was established using only 4 French virus isolates (Benmansour et al. 1997). It thus appeared relevant and necessary to extend the genetic studies to representatives of VHSV isolated from French field cases from 1971 to 1999. The primary genetic grouping (Benmansour et al. 1997) was based upon the sequence of a $\mathrm{G}$ gene region encoding amino acids (AA) 74 to 504 but revealed in addition that a particular sub-region, designated V2, accumulated most of the AA substitutions. The region which encodes AA 238 to 331 is shorter than the previous one studied and thus seems more appropriate for comparative sequence studies of numerous viral G genes.

This paper presents the results of the phylogenetic analysis of 63 French isolates, based on the sequence comparison of the V2 region of their G gene.

\section{MATERIALS AND METHODS}

Strains and virus cultivation. The studied isolates are described in Table 1. Most of the isolates were obtained from diagnostic cases from different geographic areas of France. For each isolate, RTG-2 cells were inoculated with organs from experimentallyinfected rainbow trout (spleen, anterior kidney) and incubated at $14 \pm 1^{\circ} \mathrm{C}$ (Wolf \& Quimby 1962). After 2 passages on RTG-2 cells and a third one on CHSE-214 cells (Lannann et al. 1984), plates were stored at $-20^{\circ} \mathrm{C}$ when total cytopathic effect was obtained.

RNA extraction. Viral RNA was purified from $200 \mu \mathrm{l}$ of cell culture supernatant using the 'high pure viral nucleic acid extraction kit' (Roche Molecular Biochemicals) according to the manufacturer's instructions. The RNA samples were kept frozen at $-80^{\circ} \mathrm{C}$ until analysis.

Reverse transcription and polymerase chain reaction (RT-PCR). Five $\mu \mathrm{l}$ of viral RNA were first denatured at $90^{\circ} \mathrm{C}$ for $5 \mathrm{~min}$. Denatured RNA was then subjected to reverse transcription in a total volume of $20 \mu \mathrm{l}$ containing $5 \mathrm{mM} \mathrm{MgCl}_{2}, 2 \mu \mathrm{l}$ buffer II (Perkin Elmer), $1.25 \mathrm{mM}$ each dNTP, 50 units RNase inhibitor (Promega), $80 \mathrm{U}$ MuLV (murine leukaemia virus) reverse transcriptase (Perkin Elmer) and $3.75 \mathrm{mM}$ of specific reverse primer (V2R: 5'-GATCACAGGGTGGTCAAGG-3'). Samples were incubated at $42^{\circ} \mathrm{C}$ for $1 \mathrm{~h}$. The reverse transcriptase was then denatured at $99^{\circ} \mathrm{C}$ for $10 \mathrm{~min}$. The volume was brought to $100 \mu \mathrm{l}$ by adding $80 \mu \mathrm{l}$ of the PCR mix containing $1.875 \mathrm{mM}$ $\mathrm{MgCl2}, 0.94 \mathrm{mM}$ of specific forward primer (V2F: 5'TGGGACGAAACTTTGAGAGG-3'), 2.5 U Taq polymerase (Perkin Elmer). The thermocycler (Geneamp 9600, Perkin Elmer) was programmed as follows: 1 cycle at $95^{\circ} \mathrm{C}$ for $2 \mathrm{~min}, 40$ cycles at: $95^{\circ} \mathrm{C}$ for $40 \mathrm{~s}$, $55^{\circ} \mathrm{C}$ for $40 \mathrm{~s}, 72^{\circ} \mathrm{C}$ for $40 \mathrm{~s} ; 1$ cycle at $72^{\circ} \mathrm{C}$ for $10 \mathrm{~min}$. The amplification products were separated by agarose gel electrophoresis and visualised following ethidium bromide staining. Successful amplification was assessed by the presence of the expected product of $324 \mathrm{bp}$.

Sequence determination of the PCR products. Amplified products were purified using the 'high pure PCR products purification kit' (Boehringer-Mannheim) according to manufacturer's instructions. The PCR primers were used to sequence the purified PCR products in both orientations with an ABI 373A automated sequencer (Perkin Elmer) and the ABI Prism dye terminator cycle sequencing ready reaction kit (Perkin Elmer), according to manufacturer's instructions. Sequence determination of a larger region of the glycoprotein gene (nt 220 to 1293) was also performed on some isolates using the procedure described previously (Benmansour et al. 1997).

Sequence analysis. Multiple sequence alignments were performed using Multalin (Corpet 1988) and 
Table 1. Viral haemorrhagic septicaemia virus (VHSV) isolates used in this study

\begin{tabular}{|c|c|c|c|}
\hline Virus isolate & Year of isolation & Geographic origin & Host species \\
\hline he-70 (Serotype 2) & 1970 & Denmark & Rainbow trout Oncorhynchus mykiss \\
\hline 07-71 (Serotype 1) & 1971 & Seine-Maritime, France & Rainbow trout Oncorhynchus mykiss \\
\hline 23-75 (Serotype 3) & 1975 & Eure, France & Brown trout Salmo trutta \\
\hline J77 & 1981 & Ille-et-Villaine, France & Brown trout Salmo trutta \\
\hline F48 & 1981 & Finistère, France & Rainbow trout Oncorhynchus mykiss \\
\hline G22 & 1982 & Manche, France & Rainbow trout Oncorhynchus mykiss \\
\hline 02-84 (Serotype 4) & 1984 & Seine-Maritime, France & Rainbow trout Oncorhynchus mykiss \\
\hline J59 & 1985 & Gironde, France & Rainbow trout Oncorhynchus mykiss \\
\hline J94 & 1985 & Lot-et-Garonne, France & Rainbow trout Oncorhynchus mykiss \\
\hline L59X & 1987 & Loire-Atlantique, France & Eel Anguilla anguilla \\
\hline Mak-wa88a & 1988 & Washington, USA & Coho salmon Oncorhynchus kisutch \\
\hline $23-88$ & 1988 & Seine-Maritime, France & Rainbow trout Oncorhynchus mykiss \\
\hline 1458 & 1990 & Finistère, France & Rainbow trout Oncorhynchus mykiss \\
\hline 3771 & 1990 & Landes, France & Rainbow trout Oncorhynchus mykiss \\
\hline 5898 & 1991 & Pyrénées-atlantiques, France & Rainbow trout Oncorhynchus mykiss \\
\hline 5947 & 1991 & Pyrénées-atlantiques, France & Rainbow trout Oncorhynchus mykiss \\
\hline 6023 & 1991 & Pyrénées-atlantiques, France & Rainbow trout Oncorhynchus mykiss \\
\hline XP4 & 1991 & Isère, France & Rainbow trout Oncorhynchus mykiss \\
\hline XP5 & 1991 & Savoie, France & Rainbow trout Oncorhynchus mykiss \\
\hline XP45 & 1991 & Jura, France & Rainbow trout Oncorhynchus mykiss \\
\hline XP65 & 1991 & Jura, France & Rainbow trout Oncorhynchus mykiss \\
\hline XP68 & 1991 & Puy-de-Dôme, France & Rainbow trout Oncorhynchus mykiss \\
\hline XP72 & 1991 & Jura, France & Rainbow trout Oncorhynchus mykiss \\
\hline XP75F & 1991 & Jura, France & Brown trout Salmo trutta \\
\hline YP41 & 1992 & Doubs, France & Rainbow trout Oncorhynchus mykiss \\
\hline 5785 & 1993 & Dordogne, France & Rainbow trout Oncorhynchus mykiss \\
\hline 10171 & 1993 & Dordogne, France & Rainbow trout Oncorhynchus mykiss \\
\hline 5796 & 1993 & Dordogne, France & Rainbow trout Oncorhynchus mykiss \\
\hline 5801 & 1993 & Dordogne, France & Rainbow trout Oncorhynchus mykiss \\
\hline 590 & 1993 & Pyrénées-atlantiques, France & Rainbow trout Oncorhynchus mykiss \\
\hline $\mathrm{R} 27$ & 1993 & Finistère, France & Rainbow trout Oncorhynchus mykiss \\
\hline C6382 & 1993 & Marne, France & Rainbow trout Oncorhynchus mykiss \\
\hline R22 & 1993 & Pas-de-Calais, France & Rainbow trout Oncorhynchus mykiss \\
\hline R73 & 1993 & Pas-de-Calais, France & Rainbow trout Oncorhynchus mykiss \\
\hline R86 & 1993 & Pas-de-Calais, France & Rainbow trout Oncorhynchus mykiss \\
\hline R104 & 1993 & Pas-de-Calais, France & Rainbow trout Oncorhynchus mykiss \\
\hline 6491 & 1993 & Pyrénées-atlantiques, France & Rainbow trout Oncorhynchus mykiss \\
\hline R94 & 1993 & Meuse, France & Rainbow trout Oncorhynchus mykiss \\
\hline $\mathrm{R} 67$ & 1993 & Aveyron, France & Rainbow trout Oncorhynchus mykiss \\
\hline R68 & 1993 & Orne, France & Rainbow trout Oncorhynchus mykiss \\
\hline S75 & 1994 & Seine-Maritime, France & Rainbow trout Oncorhynchus mykiss \\
\hline S93 & 1994 & Seine-Maritime, France & Rainbow trout Oncorhynchus mykiss \\
\hline 3608 & 1994 & Dordogne, France & Rainbow trout Oncorhynchus mykiss \\
\hline 4231 & 1994 & Dordogne, France & Rainbow trout Oncorhynchus mykiss \\
\hline 4957 & 1994 & Dordogne, France & Rainbow trout Oncorhynchus mykiss \\
\hline 2585 & 1994 & Landes, France & Rainbow trout Oncorhynchus mykiss \\
\hline S1 & 1994 & Pas-de-Calais, France & Rainbow trout Oncorhynchus mykiss \\
\hline V249 & 1994 & Pas-de-Calais, France & Rainbow trout Oncorhynchus mykiss \\
\hline V806 & 1994 & Pas-de-Calais, France & Rainbow trout Oncorhynchus mykiss \\
\hline S31 & 1994 & Meuse, France & Rainbow trout Oncorhynchus mykiss \\
\hline S45 & 1994 & Aveyron, France & Rainbow trout Oncorhynchus mykiss \\
\hline S41 & 1994 & Eure-et-Loir, France & Rainbow trout Oncorhynchus mykiss \\
\hline S79 & 1994 & Somme, France & Rainbow trout Oncorhynchus mykiss \\
\hline $\operatorname{Sco95}(860 / 94)^{\mathrm{a}}$ & 1995 & Scotland & Turbot Scophthalmus maximus \\
\hline T6 & 1995 & Seine-Maritime, France & Rainbow trout Oncorhynchus mykiss \\
\hline $\mathrm{T} 7$ & 1995 & Seine-Maritime, France & Rainbow trout Oncorhynchus mykiss \\
\hline U19 & 1996 & Gironde, France & Rainbow trout Oncorhynchus mykiss \\
\hline W94 & 1998 & Jura, France & Rainbow trout Oncorhynchus mykiss \\
\hline $\mathrm{X} 163$ & 1998 & Ariège, France & Largemouth bass Micropterus salmoides \\
\hline X164 & 1998 & Ariège, France & Pike Esox lucius \\
\hline X165 & 1998 & Ariège, France & Rainbow trout Oncorhynchus mykiss \\
\hline X166 & 1998 & Hautes-Garonne, France & Rainbow trout Oncorhynchus mykiss \\
\hline X168 & 1998 & Hautes-Pyrénées, France & Rainbow trout Oncorhynchus mykiss \\
\hline $\mathrm{X} 4$ & 1999 & Moselle, France & Pike Esox lucius \\
\hline $\mathrm{X} 167$ & 1999 & Aveyron, France & Rainbow trout Oncorhynchus mykiss \\
\hline X169 & 1999 & Landes, France & Rainbow trout Oncorhynchus mykiss \\
\hline
\end{tabular}


ClustalX (Thompson et al. 1997) after exclusion of the primer sequences. Phylogenetic trees were constructed using the neighbour-joining (NJ) method (Saitou \& Nei 1987) implemented in the ClustalX program. Alternative programs of phylogeny contained in PHYLIP (Phylogeny Inference Package, Version 3.5c) based on parsimony (DNAPARS) and maximum likelihood (DNAML) were also used. When several isolates had the same nucleotide sequence, the analysis was restricted to one representative isolate. In this case, the earliest isolate was chosen. Statistical assessment of the topology of the phylogenetic tree was made by 1000 bootstrap trials. The trees were printed using Treeview (Page 1996).

Neutralisation test. Twenty-five $\mu \mathrm{l}$ of serial 2-fold step dilutions of MAb 168m4, obtained from mice immunised with virus strain 07-71 (Béarzotti et al. 1995), were incubated with an equal volume of VHSV containing $10000 \mathrm{pfu} \mathrm{ml}^{-1}$. Duplicate rows were performed on 96 well plates for each virus isolate. After $16 \mathrm{~h}$ incubation at $5 \pm 3^{\circ} \mathrm{C}, 150 \mu \mathrm{l}$ of CHSE-214 cell suspension in Eagle's MEM medium were added in each well. After incubation for $4 \mathrm{~d}$ at $14^{\circ} \mathrm{C}$, the cells were fixed with $10 \%$ formalin and stained with a $1 \%$ crystal violet solution. The neutralising titre was expressed as the reciprocal of the highest dilution of serum that resulted in $50 \%$ protection of the cells compared to positive and negative controls.

\section{RESULTS}

\section{Nucleotide sequencing and sequence comparison of the $\mathrm{V} 2$ region of the glycoprotein gene}

Using V2R and V2F primers, a 324 bp amplification product was obtained for all analysed isolates (data not shown). The sequence of the V2 region of the glycoprotein gene was determined for 63 VHSV strains isolated between 1971 and 1999. The data were submitted to the EMBL nucleotide sequence database and had been assigned Accession Numbers AJ487051 to AJ487080. Multiple alignments of the obtained nucleotide sequences (not shown), and the deduced amino-acid se-

238

07-71 IVAGHHPWGL TMACTVTFCG TEWIKTDLGD LIQVTGPGGT RKLTPNKCVN TDIQMRGATD DFSYLNHLIT MMAQRTECLD AHSDITASGK VSSF

\begin{tabular}{|c|c|c|c|c|c|c|c|c|c|c|}
\hline s45 & - & .. & E....... & . . K..... & $\bullet$ & & & & & \\
\hline 4957 & & $\cdots$ & $\ldots$ & ......E. & ......... & . . v & ... & $\cdots \cdot$ & & ..P. \\
\hline & ........ & $\ldots \ldots \ldots$ & E........ & ........ & ......... & ..v....... & .......... & $\ldots \ldots$ & $\ldots \ldots \ldots$ & \\
\hline r27 & . & $\ldots$ & $\ldots$ & ........ & .......... & ..v....... & $\ldots$ & & $\ldots \ldots$ & \\
\hline$r 68$ & $\ldots \ldots$ & $\ldots \ldots \ldots$ & $\ldots$ & ......8. & ........... & .v...... & ........... & 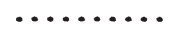 & $\ldots \ldots \ldots$ & \\
\hline xp45 & $\ldots \ldots \ldots$ & $\ldots \ldots \ldots$ & $\ldots$ & …...E. & $\cdots \cdots \cdots$ & & $\ldots \ldots \ldots \ldots$ & $\cdots \cdots$ & $\ldots \ldots$ & \\
\hline & & 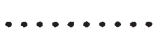 & $\ldots \ldots$ & ......... & & $\ldots v$ & ..... & & & \\
\hline 0171 & $\ldots \ldots \ldots$ & $\ldots \ldots \ldots \ldots$ & $\ldots \ldots$ & $\ldots \ldots \ldots \ldots$ & G...... & $\ldots v \ldots \ldots \ldots$ & $\ldots$ & & & \\
\hline 3771 & $\ldots \ldots \ldots$ & $\ldots \ldots \ldots$ & A. $\ldots \ldots \ldots$ & $\ldots \ldots$ & G..... & $\ldots v$ & $\ldots \ldots$ & & $\cdots \ldots$ & \\
\hline 5796 & م & $\ldots \ldots \ldots$ & A....... & $\ldots \ldots \ldots \ldots$ & G....... & ...v. & .......... & $\ldots \ldots \ldots \ldots$ & $\ldots \ldots \ldots$ & \\
\hline xp41 & $\ldots \ldots \ldots$ & $\cdots \ldots$ & A. $\ldots \ldots \ldots$ & $\ldots \ldots \ldots \ldots$ & $G \ldots \ldots \ldots$ & $\ldots v \ldots \ldots$ & $\ldots \ldots \ldots$ & $\ldots \ldots \ldots \ldots$ & $\cdots \ldots \ldots$ & \\
\hline 5801 & - & ... & $\cdots$ & $\cdots$ & $G \ldots \ldots \ldots$ & $\ldots v$ & .......... & $\ldots \ldots$ & $\ldots \ldots$ & \\
\hline 831 & ........ & $\ldots \ldots \ldots \ldots$ & A........ & ....... & $G \ldots \ldots \ldots$ & ..v...... & ........... & & & \\
\hline $\mathrm{s} 41$ & $\ldots \ldots \ldots$ & $\ldots \ldots \ldots \ldots$ & A. $\ldots \ldots \ldots$ & $\ldots$ & G..... & $\ldots$ & .......... & $\ldots \ldots \ldots \ldots$ & $\ldots \ldots \ldots$ & \\
\hline 5947 & $\cdots$ & $\ldots$. & $\ldots$. & $\ldots \ldots$ & G...... &.$v$ & .......... & $\ldots \ldots$ & $\ldots \ldots$ & \\
\hline w94 & $\ldots \ldots \ldots$ & $\ldots$. & AD........ & $\cdots$ & $G \ldots \ldots \ldots$ & $\cdots$ & ........... & $\cdots$ & $\cdots \cdots$ & \\
\hline $\mathbf{s 7 9}$ & ...... & •...... & $\ldots$. & • . . & G. & $\ldots v$ & .......... & $\cdots$ & \#.WE. & \\
\hline r73 & $\cdots \ldots \ldots$ & $\ldots \ldots \ldots \ldots$ & $\ldots$. & $\cdots$ & G..... & $\cdots$ & ........... & $\ldots$. & $\ldots \ldots$ & \\
\hline xp68 & $\ldots \ldots \ldots$ & $\ldots \ldots \ldots \ldots$ & $\ldots \ldots$ & $\ldots \ldots \ldots$ & G........ & $\ldots$ & .......... & $\ldots \ldots \ldots \ldots$ & $\cdots \ldots$ & \\
\hline t6 & . & $\ldots$. & $\ldots$ & $\cdots$ & G. & $\ldots v$ & ... & .. & $\cdots$ & \\
\hline t7 & $\cdots \cdot$ & $\ldots$ & $\ldots$ & & G...R.... & $\ldots v$ & $\cdots$ & $\cdots$ & $\cdots \cdots$ & \\
\hline s93 & $\ldots \ldots$ & $\cdots$ & $\ldots$ & …A. & G.... T. & $\ldots v$ & $\ldots$. & $\ldots$ & $\ldots \ldots$ & \\
\hline j59 & $\ldots \ldots$ & $\ldots$ & $\ldots$ & $\cdots \ldots$ & ...R.... & ..v & ...... & $\cdots$ & $\cdots$ & \\
\hline 1458 & $\ldots \ldots \ldots$ & $\ldots \ldots \ldots \ldots$ & $\ldots$ & ... & $\ldots \ldots R \ldots$ & . v & $\ldots \ldots \ldots \ldots$ & $\ldots .$. & $\ldots \ldots$ & \\
\hline 577 & $\ldots \ldots$ & $\ldots \ldots \ldots \ldots$ & $\ldots$ & .. $\mathbf{k}$ & $\cdots$ & & $\ldots \ldots$ & $\cdots$ & $\ldots \ldots$ & \\
\hline r104 & . & $\cdots$ & & . . & ...R.... & & & & . & \\
\hline$\nabla 806$ & $\ldots$ & ... & .. & . $\mathbf{R}$. & ...R.... & & & & $\cdots$ & \\
\hline s1 & $\ldots$ & $\ldots$ & .D &. $\mathbf{k}$ & . . & & & & ... & \\
\hline he70 & $\ldots \ldots \ldots$ & $\cdots$ & $\cdots$ & ... . . & $\cdots$ & & . . . . . & $\ldots \ldots \ldots \ldots$ & $\cdots \cdot$ & \\
\hline $3-75$ & & & & ...... & .I...R. & & & & & I. \\
\hline r94 & $\ldots \ldots$ & $\ldots \ldots \ldots R$ & & $\cdots$ & G....R. & & $\cdots$ & & - & \\
\hline xp4 & $\ldots \ldots$ & - & & & G. & & & & & \\
\hline 59x & 0.0 & & & & & & & & & \\
\hline$c 095$ & ......... & $\cdots$ & & . . K...Q & $\mathbf{R} \ldots \mathbf{R}$. &. $\mathrm{N}$ & $\cdots$ & …н & $\cdots$ & \\
\hline 188 & & & & $\cdots \cdot \mathbf{Q}$ & R., S.R & & & & & \\
\hline & & & & & & & & & & \\
\hline
\end{tabular}

Fig. 1. Deduced amino-acid sequence homology among VHSV isolates. Multiple alignment of the deduced amino acid (AA) sequence (corresponding to AA 238 to 331 of the glycoprotein) of isolates studied along with the corresponding sequence of Isolates Sco95 and mak-wa88 (Benmansour et al. 1997). Multiple alignment was performed using Multalin 
quences (Fig. 1) of the studied isolates, were performed along with previously published sequences of the glycoprotein gene. Sequences of strains 07-71, he-70, 23-75 and 02-84 were determined as a control and were found to be identical to already published data.

Sequence comparison with strain 07-71 showed that no deletions or insertions occurred in the studied coding region of any isolate. Overall, the sequence homology was high between strains: the percentage of nucleotide substitutions between French continental isolates never exceeded $6.9 \%$, and the only isolate from brackish water in France (L59X) was 9.7 to $13.8 \%$ different to the other French strains. Compared to isolate Sco95, L59X was $4.4 \%$ different at the nucleotide level.

The sequences of many isolates were found to be identical to each other. For instance, a group of 12 isolates shared $100 \%$ identity $(3771,10171,3608,4231$, $5801,5898,6023,6491$, c6382, S31, S75, and U19). Further isolates were also very similar to this group, including isolate 5796 (silent mutation $\mathrm{C} \rightarrow \mathrm{T}$ at Position 789), isolates 590 and 5947 (silent mutation $A \rightarrow G$ at position 781 and a $\mathrm{T} \rightarrow \mathrm{C}$ mutation at Position 961), and isolate $\mathrm{S} 79(1 \mathrm{G} \rightarrow \mathrm{A}$ mutation leading to aminoacid change G-327-E). Most of these strains were obtained from fish raised in the south-west of France, except c6392, S31, S75 which came from the departments of Marne, Meuse, or Seine-Maritime, respectively. Strains S41 $(2 \mathrm{~T} \rightarrow \mathrm{C}$ mutations at positions 861 and 897 and an $\mathrm{A} \rightarrow \mathrm{C}$ mutation at position 948 ), and YP41 ( $\mathrm{T} \rightarrow \mathrm{C}$ mutation at position 897), were also closely related to this group.

Another group of 4 isolates showed $100 \%$ homology to each other (XP45, XP65, XP72, XP75f). These strains were isolated in 1991 in the Jura region from rainbow trout from the same fish farm, except XP75f which was isolated from a wild brown trout Salmo trutta caught in the river very close to the farm. Isolates R27 and R68 were very similar to this group with few nucleotide substitutions which did not induce any amino-acid change.

Isolates XP4 and XP5, both isolated from rainbow trout in 1991, were found identical to each other. They were obtained from fish farms located in 2 French Alpes departments: Savoie and Isere. Isolate R94 was similar to XP4 and XP5 with one silent mutation at position 744 .

Complete homology was also observed for the following isolates: F48 (Finistère, 1991) and G22 (Manche, 1982) both in the north-western part of the country, 2585 (Landes, 1994) and 5785 (Dordogne, 1993), as well as the 3 isolates R73, R86 (Pas-de-Calais, 1993) and V249 (Pas-de-Calais, 1994). In all these cases there was a good correlation between the sequence of the isolates and their geographic locations.
Six other recent strains, isolated during VHS outbreaks that occurred in several departments from the south-west of the country in 1998, were also identical to each other (X163-X168). Interestingly these strains were also identical to an earlier isolate (4957 from rainbow trout in 1994) also from the south-west (Dordogne). Besides, although they were mainly from rainbow trout, 2 of these isolates were recovered from other fish species: largemouth bass Micropterus salmoides (X164) and pike Esox lucius (X165).

S1 and V806 isolates had the same nucleotide sequence: they were both recovered in 1994 from rainbow trout in the Pas-de-Calais department. R104, also from the Pas-de-Calais, was similar, with only 1 silent substitution at position 717. X169, recently isolated from rainbow trout in 1999, had the same sequence as X4 obtained from pike in 1998.

\section{Phylogenetic analysis of the isolates}

The evolutionary relationships between the VHSV isolates were investigated by the NJ method, based on the analysis of the 710 to $995 \mathrm{nt}$ region of the $\mathrm{G}$ gene of the studied French isolates together with isolates representative of the major genotypes.

The phylogenetic tree is detailed in Fig. 2. The tree was divided into 3 branches (Pacific, Atlantic and continental European), which were supported by high bootstrap values according to previously published results. Other methods of analysis (DNAPARS, DNAML) produced the same tree topology (data not shown). When the same analysis was carried out using a larger region of the glycoprotein gene, corresponding to AA 74 to 504 (nt 220 to 1293), on a limited number of VHSV isolates, the topology of the tree was found identical to the one obtained using the V2 region, and the branching of the isolates was similar (data not shown).

All French continental isolates were grouped together with a bootstrap value of $97.7 \%$ (genotype I). Further branching could be distinguished within genotype I, but sub-branches were supported by lower bootstrap values (Fig. 2). Four sub-groups could thus be defined. These are tentatively designated Ia, Ib, Ic, and Id. Sub-group Ia contains isolates clustering with strain 07-71 (XP68, R67, S45, 4957, 5785, X4，XP45, R27). Sub-group Ib contains isolates clustering with strain 02-84 (R22, R73，R86, V249, S93，T6，T7，F48, R94，XP64，W94，5796，3771，S79，XP41，5947，S41). Sub-group Ic contains representative of serotypes II and III (He70 and 23-75, respectively) and isolates 1458, J77, S1 and R104. Isolates J59 and J94 appeared to segregate on a separate branch (sub-group Id), although the bootstrap value was only $24.5 \%$. Interest- 
ingly, it was found that these isolates were not neutralised by MAb 105c10 (not shown) which is directed against a very conserved epitope located at AA 139 to 140. As is found in neutralisation, escape mutant isolates J59 and J94 had mutations S-140-D or S-140-N (not shown).

Isolate L59X recovered from elvers in the Loire estuary, thus considered to be of marine origin, was found to segregate with isolate Sco95 (Genotype II), which further confirms the existence of this genotype and shows that the geographic localisation of isolates belonging to this genotype goes beyond the British Isles zone.

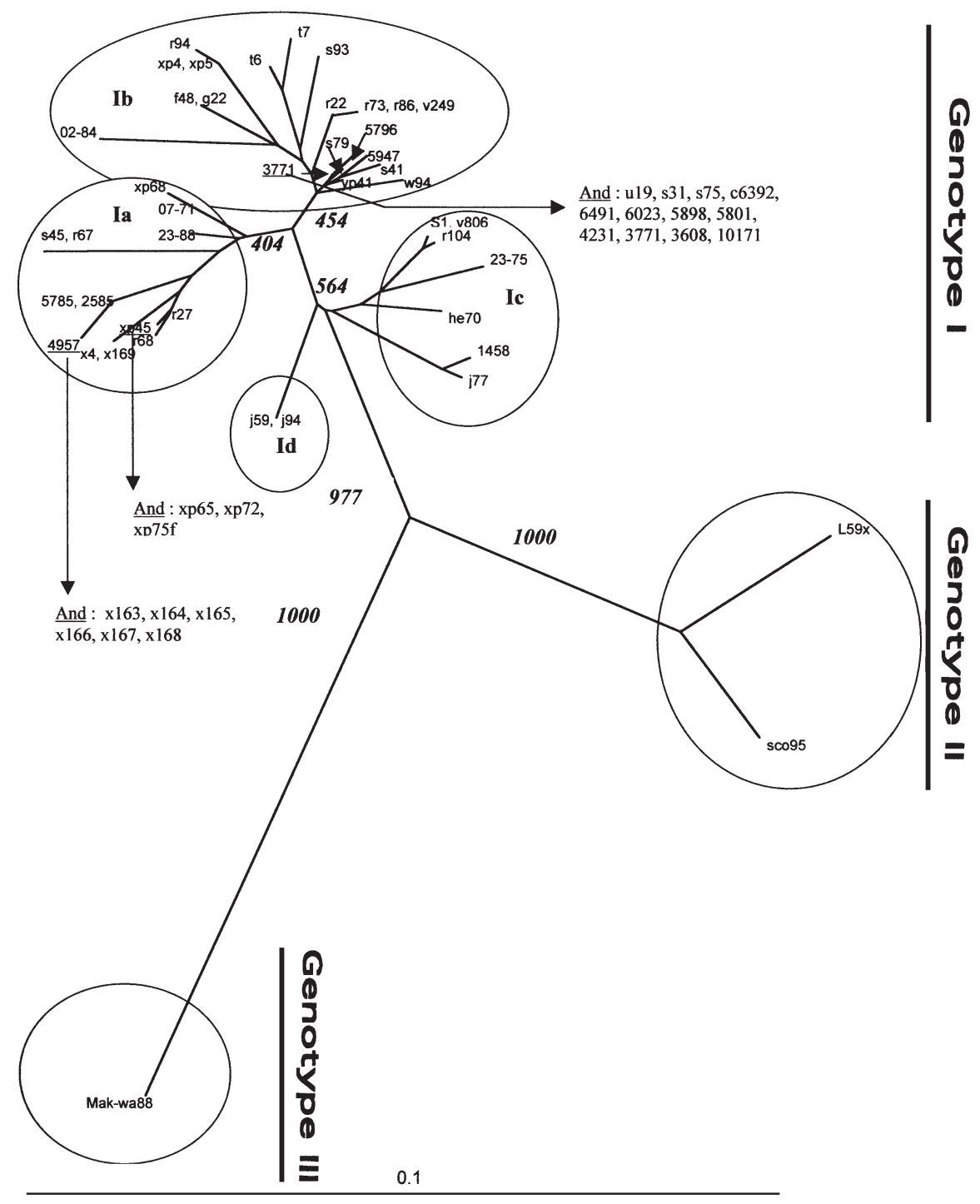

Fig. 2. Phylogenetic classification of French VHSV isolates. Phylogenetic tree was constructed based on analysis of nt 710 to 995 of the coding region of the glycoprotein gene using the neighbour-joining (NJ) method. Bootstrap values for 1000 replicates are shown in bold characters for major branches. The scale bar indicates the number of substitutions per nucleotide site

\section{Analysis of the MAb 168m4 epitope}

As it has been shown that the epitope of neutralising MAb 168m4 mapped to AA 254 to 259 of the glycoprotein gene which is included in the $\mathrm{V} 2$ region (Béarzotti et al. 1995), neutralisation tests were performed with this MAb. Comparison of amino-acid sequences surrounding the $168 \mathrm{~m} 4$ epitope of non-neutralised isolates and the amino-acid sequence from virus strain 07-71 was performed (Fig. 3). Indeed, mutations at positions 257, 258 or 259 were found in all isolates. Mutation T-258-E was the most frequent change affecting the reactivity of MAb $168 \mathrm{~m} 4$ antibody. This mutation was not reported for $168 \mathrm{~m} 4$ neutralisation escape mutants, nor for other field isolates, which were not neutralised with this antibody (Benmansour et al. 1997). Mutation E-259-D was also detected in several isolates and was often associated with another mutation (T-258-E or T-258-K). Isolates R94, XP4 and XP5 were not neutralised and had 2 adjacent mutations (G-257-R and T-258-E). Isolates T6 and T7, also non-reactive, had an E-259-D change, that was also reported for a $168 \mathrm{~m} 4$ neutralisation escape mutant (Benmansour et al. 1997). On the other hand, a T-258-A mutation did not seem to greatly affect the $168 \mathrm{~m} 4$ reactivity since this mutation was detected in many isolates that were neutralised with MAb 168m4, however some of them were partly neutralised (not shown).

\section{DISCUSSION}

The aim of the present study was to achieve a genetic analysis of VHSV isolates from France to delineate the VHSV diversity and spread in this country. Although similar studies have been reported to classify VHSV strains from distant geographical regions of the world, this is, to our knowledge, the first study on a large number of virus isolates from the same country. Genetic analysis was performed by comparison of a variable region of the glycoprotein gene, designated V2 (Benmansour et al. 1997), that accumulates most of the mutations. To this aim, PCR primers were derived from conserved 
sequences surrounding the V2 region. This primer set allowed efficient amplification of the 63 isolates tested and the V2 nucleotide sequence could be determined. As expected, mutations were detected in the V2 region.

The topology of the phylogenetic tree obtained in the present study was in agreement with previous reports (Benmansour et al. 1997, Stone et al. 1997). We found that all French continental VHSV isolates belong to the same lineage, described as genotype I (Benmansour et al. 1997) or genotype III (Stone et al. 1997), grouping isolates from continental Europe. It is suggested that this group be designated 'Genotype I' since it contains the most ancient isolates.

As already suggested (Benmansour et al. 1997), subgroups could be distinguished within genotype I. The majority of the studied isolates are grouped in subgroups Ia or Ib. These sub-groups respectively contained previously described isolates 07-71 (serotype 1) and 02-84 (serotype 4). Few isolates clustered with sub-group Ic, also containing strain 23-75 (serotype 3) and strain He70 (serotype 2). However, isolates 23-75 and He70 were on separate branches when analysing a larger region of the G gene (Benmansour et al. 1997, other data not shown). J59 and J94 appear to constitute a new sub-group (Id) that might be of biological significance since these isolates were not neutralised by MAb c10 (not shown). It should be pointed out that these sub-groups were not supported by high bootstrap values, thus grouping may change with the addition of more sequences in the future, or analysis of other genes.

Within genotype I, there was no obvious correlation between the genetic classification and the antigenic properties. MAb 168m4, which was obtained after immunisation of a mice with isolate 07-71, neutralised many isolates distributed in sub-groups Ia, Ib, Ic, or Id. Similarly, non-neutralised isolates were not affiliated to a specific sub-group. However, detailed comparison of the amino-acid sequences of non-neutralised isolates showed that they were mutated in positions 257 , 258 or 259, which is in agreement with the localisation of the MAb 168m4 epitope (Béarzotti et al. 1995). Although some of the mutations affecting the reactivity of Mab 168m4 were described previously (Benmansour et al. 1997), a new mutation was characterised (T258-A) thus further extending the mutational analysis of the $168 \mathrm{~m} 4$ epitope.

Often, a good correlation was noticed between the geographical origin of the isolates and their position on the phylogenetic tree. However, there was no obvious link between the fish-host species and the VHSV genogroup, as previously reported (Benmansour et al. 1997). Indeed, complete homology was detected between sequences of isolates obtained from different

\begin{tabular}{|c|c|c|c|c|}
\hline & 248 & 258 & 268 & 278 \\
\hline $07-71$ & TMACTVTFCG & TEW IKTDLGD & LIQVTGPGGT & RKLTPNKCVN \\
\hline 585 & $\ldots \ldots \ldots$ & E....... & $\ldots \ldots \ldots$. & … \\
\hline 957 & $\ldots \ldots$ & $\mathbf{E} \ldots \ldots \ldots$ & . . . E. & ....I. \\
\hline 22 & $\ldots \ldots$ & EK....... & $\ldots \ldots \ldots$ & $G \ldots \ldots$ \\
\hline 27 & $\ldots \ldots \ldots$ & KD....... & $\ldots \ldots \ldots$ & $\ldots \ldots \ldots$ \\
\hline 67 & $\ldots \ldots \ldots$ & E....... & $\ldots$ K...... & $\ldots \ldots \ldots$ \\
\hline 68 & $\ldots \ldots$ & KD....... & . . EE. & $\ldots \ldots \ldots$ \\
\hline 73 & $\ldots \ldots \ldots$ & ET....... & $\ldots \ldots \ldots$ & $G \ldots \ldots$ \\
\hline 86 & $\ldots \ldots$ & ET. . . . . . & $\ldots \ldots \ldots$ & $G \ldots \ldots$ \\
\hline 94 & $\ldots \ldots \ldots R$ & E....... & $\ldots \ldots \ldots$ & G...K... \\
\hline 45 & $\ldots \ldots \ldots$ & E........ & $\ldots k \ldots \ldots$ & $\ldots \ldots \ldots$ \\
\hline S93 & $\ldots \ldots \ldots$ & ED...... & $\ldots A \ldots \ldots$ & G....... \\
\hline 6 & $\ldots \ldots \ldots$ & .D....... & $\ldots \ldots \ldots$ & G...R... \\
\hline T7 & $\ldots \ldots$ & .D........ & $\ldots \ldots \ldots$ & G...R... \\
\hline V249 & $\ldots \ldots \ldots$ & Ет...... & $\ldots \ldots \ldots$ & $G \ldots \ldots$ \\
\hline XP45 & $\ldots \ldots \ldots$ & KD....... & $\ldots \ldots$. . & $\ldots \ldots \ldots$ \\
\hline XP4 & $\ldots \ldots \ldots R$ & E....... & $\ldots \ldots \ldots$ & G...K.... \\
\hline P5 & $\ldots \ldots \ldots R$ & E....... & $\ldots \ldots \ldots$ & G...K... \\
\hline XP65 & $\ldots \ldots$ & KD........ & $\ldots \ldots E$. & $\ldots \ldots \ldots$ \\
\hline XP72 & $\ldots \ldots$ & KD........ & $\ldots \ldots \ldots$. & $\ldots \ldots \ldots$ \\
\hline XP75F & $\cdots \cdots$ & KD....... & $\ldots \ldots E$. & . . . . \\
\hline $\mathrm{J} 77$ & $\ldots$ & .D...... & . K...... & $\ldots$. R... \\
\hline $\mathrm{X} 4$ & $\ldots \ldots$ & .D...... & ...EE. & $\ldots \ldots \ldots$ \\
\hline $\mathrm{x} 163$ & $\ldots \ldots \ldots \ldots$ & E....... & $\ldots \ldots E$. & $\ldots \ldots \ldots I$ \\
\hline $\mathrm{X} 164$ & $\ldots \ldots \ldots \ldots$ & E....... & ....E. & $\ldots \ldots \ldots I$ \\
\hline X169 & $\ldots \ldots \ldots$ & .D...... & ....E. & $\ldots \ldots \ldots$ \\
\hline 1458 & $\cdots \cdots$ & D..... & $\ldots \ldots$ & $\ldots$. R . . \\
\hline
\end{tabular}

Fig. 3. Analysis of the $168 \mathrm{~m} 4$ epitope of non-neutralised VHSV isolates. Sequence in the vicinity of the MAb 168m4 epitope (AA 254 to 259 of the glycoprotein gene, shaded in grey) of non-neutralised VHSV isolates are compared to the 07-71 strain. Amino-acid mutations associated with lack of reactivity towards MAb $168 \mathrm{~m} 4$ are in bold

fish species (e.g. X163, X164 and X165 from rainbow trout Oncorhynchus mykiss, largemouth bass Micropterus salmoides and pike Esox lucius, respectively), which supports the hypothesis that they could be infected by the same virus strain. Within genotype I, the extent of genetic variation between isolates was low $(<7 \%)$, probably indicating a low mutation rate. This is further demonstrated by the complete sequence identity obtained in several cases. For instance, a set of 13 isolates obtained between 1990 and 1996 had the same V2 sequence as isolate 3771 (sub-group Ib, Fig. 2).

Only 1 isolate (L59X) was affiliated to genotype II, containing isolates from marine fish species such as Atlantic cod Gadus morhua (Stone et al. 1997) or turbot Scophthalmus maximus (Benmansour et al. 1997, Stone et al. 1997). Interestingly, L59X was isolated from wild elvers Anguilla anguilla caught in the river Loire estuary (Castric et al. 1992) showing that this migrating fish species can also be naturally infected by a VHSV strain of genotype II. It was previously reported (Castric \& Jeffroy, 1991) that isolate L59X is pathogenic by intra-peritoneal injection to sea bass Dicentrarchus labrax, sea bream Sparus aurata and turbot Scophtalmus maximus. These results are in agreement with recent data from Snow \& Smail (1999) who showed that a marine isolate of VHSV (860/14) 
from turbot, which can also be classified within genotype II, is highly pathogenic to turbot under various experimental conditions, including by bath. However, whether L59X could infect turbot by bath exposure is not yet known.

It could be hypothesised that, as a amphihaline fish species, eel Anguilla anguilla could potentially introduce a marine VHSV strain into the freshwater environment. However, to the authors' knowledge, this situation has not been reported so far. Preliminary observations showed that isolate L59X is pathogenic to rainbow trout Oncorhynchus mykiss when inoculated by the intra-peritoneal route (Castric et al. 1992), but is not pathogenic to this species nor to brown trout Salmo trutta by immersion (Castric unpubl. results). The marine isolate 860/94 from turbot Scophthalmus maximus (isolate Sco95 in the present paper) is also pathogenic to rainbow trout by intra-peritoneal injection (Snow \& Cunningham 2000), but not by bath immersion, like all marine VHSV isolates tested so far (Olesen pers. comm. cited in Snow \& Cunningham 2000). In this last report, the authors also demonstrated that the virulence of marine isolate 860/94 (Sco95) towards rainbow trout increases after several passages in vivo, but unfortunately, the infection could not be performed by bath. Taken together, these observations tend to show that marine strains of VHSV are a low risk for rainbow trout under natural conditions. Nevertheless, possibilities of transfer of such a strain into the freshwater environment should be reduced to a minimum, since these strains could theoretically become pathogenic when placed under favourable conditions.

In this study, sequencing was restricted to the V2 region of the glycoprotein gene. However, phylogenetic analysis showed that the sequence information contained in this region was sufficient to construct phylogenetic trees that were topologically similar to trees obtained after sequencing the entire open reading frame of the G gene. Therefore, V2 sequencing could provide a suitable molecular tool to investigate the origin of a local outbreak and thus would help to understand the epidemiology of the disease.

Acknowledgements. This work was supported by the AFSSA and by the 'Direction générale de l'alimentation' from the French Ministry of Agriculture. Thanks are due to Departmental laboratories (LDA 40 and LDA 62, France) for providing numerous VHSV isolates used in this study. Monoclonal Antibody $168 \mathrm{~m} 4$ was kindly provided by M. Béarzotti (Institut National de la Recherche Agronomique, Jouy-en-Josas, France)

\section{LITERATURE CITED}

Béarzotti M, Monnier AF, Vende P, Grosclaude J, de Kinkelin P, Benmansour A (1995) The glycoprotein of viral hemor- rhagic septicemia virus (VHSV): antigenicity and role in virulence. Vet Res 26:413-422

Benmansour A, Basurco B, Monnier AF, Vende P, Winton JR, de Kinkelin P (1997) Sequence variation of the glycoprotein gene identifies three distinct lineages within field isolates of viral haemorrhagic septicaemia virus, a fish rhabdovirus. J Gen Virol 78: 2837-2846

Castric J, de Kinkelin P (1980) Occurence of viral haemorrhagic septicemia in rainbow trout Salmo gardneri Richardson reared in sea-water. J Fish Dis 3:21-27

Castric J, de Kinkelin P (1984) Experimental study of the susceptibility of two marine fish species, seabass (Dicentrarchus labrax) and turbot (Scophthalmus maximus), to viral haemorrhagic septicaemia. Aquaculture 41:203-212

Castric J, Jeffroy J (1991) Experimentally induced diseases in marine fish with IHNV and a rhabdovirus of eel. Eur Aquacult Soc, Bredene, Spec Publ 14:54-55

Castric J, Jeffroy J, Bearzotti M, de Kinkelin P (1992) Isolation of viral haemorrhagic septicaemia virus (VHSV) from wild elvers Anguilla anguilla. Bull Eur Assoc Fish Pathol 12: 21-23

Corpet F (1988) Multiple sequence alignment with hierarchical clustering. Nucleic Acids Res 16:10881-10890

Horlyck V, Mellergard S, Dalsgaard I, Jørgensen PEV (1984) Occurence of VHS in danish maricultured rainbow trout. Bull Eur Assoc Fish Pathol 4:11-13

Jensen NJ, Bloch B, Larsen JL (1979) The ulcus syndrome in cod (Gadus morhua) III. A preliminary virological report. Nord Vet Med 31:436-442

Jørgensen PEV, Olesen NJ (1987) Cod Ulcus syndrome rhabdovirus is indistinguishable from the Egtved (VHS) virus. Bull Eur Assoc Fish Pathol 7, 73-74

Lannan CN, Winton JR, Fryer JL (1984) Fish cell lines: establishment and characterization of nine cell lines from salmonids. In Vitro 20:671-676

Meyers TR, Winton JR (1995) Viral hemorrhagic septicaemia virus in North America. In: Faisal M, Hetrick FM (eds) Annual Review of Fish Diseases, Vol 5. Pergamon Elsevier Sciences, Oxford, p 3-24

Mortensen HF, Heuer OE, Lorenzen N, Otte L, Olesen NJ (1999) Isolation of viral haemorrhagic septicaemia virus (VHSV) from wild marine fish species in the Baltic Sea, Kattegat, Skagerrak and the North Sea. Virus Res 63: 95-106

Page RDM (1996) TREEVIEW: an application to display phylogenetic trees on personal computers. Comput Appl Biosci 12:357-358

Ross K, Mac Carthy U, Huntly PJ, Wood BP, Stuart D, Rough EI, Smail DA, Bruno DW (1994) An outbreak of viral haemorrhagic septicaemia (VHS) in turbot Scophthalmus maximus in Scotland. Bull Eur Assoc Fish Pathol 14: $213-214$

Saitou N, Nei M (1987) The neighbor-joining method: a new method for reconstructing phylogenetic trees. Mol Biol Evol 4:406-425

Schutze H, Mundt E, Mettenleiter TC (1999) Complete genomic sequence of viral hemorrhagic septicemia virus, a fish rhabdovirus. Virus Genes 19:59-65

Snow M, Cunningham CO (2000) Virulence and nucleotide sequence analysis of marine viral haemorrhagic septicaemia virus following in vivo passage in rainbow trout Onchorhynchus mykiss. Dis Aquat Org 42:17-26

Snow M, Smail DA (1999) Experimental susceptibility of turbot Scophthalmus maximus to viral haemorrhagic septicaemia virus isolated from cultivated turbot. Dis Aquat Org 38:163-168

Snow M, Cunningham CO, Melvin WT, Kurath G (1999) 
Analysis of the nucleoprotein gene identifies distinct lineages of viral haemorrhagic septicaemia virus within the European marine environment. Virus Res 63:35-44

Stone DM, Way K, Dixon PF (1997) Nucleotide sequence of the glycoprotein gene of viral haemorrhagic septicaemia (VHS) viruses from different geographical areas: a link between VHS in farmed fish species and viruses isolated from North Sea cod (Gadus morhua L.). J Gen Virol 78: $1319-1326$

Thompson JD, Gibson TJ, Plewniak F, Jeanmougin F, Higgins

Editorial responsibility: Carey Cunningham,

Aberdeen, Scotland, UK
DG (1997) The ClustalX windows interface: flexible strategies for multiple sequence alignment aided by quality analysis tools. Nucleic Acids Res 24:4876-4882

van Regenmortel MHV, Fauquet CM, Bishop DHL, Carstens EB and 7 others (eds) (2000) Virus taxonomy: the classification and nomenclature of viruses. The Seventh Report of the International Committee on Taxonomy of Viruses. Academic Press, SanDiego

Wolf K, Quimby MC (1962) Established eurythermic line of fish cells in vitro. Science 135:1065-1066

Submitted: December 15, 2001; Accepted: June 7, 2002 Proofs received from author(s): September 9, 2002 